\title{
Lichenicolous fungi in Iğdır province, Turkey
}

Kenan Yazici $^{1}$ and Javier Etayo ${ }^{2}$

Received: 5 July, 2013. Accepted: 14 August, 2013

\begin{abstract}
As a result of lichenological exploration in the province of Iğdır, Turkey, forty species of lichenicolous fungi belonging to eighteen genera were identified on twenty-seven different lichenized fungi. Four lichenicolous fungi-Arthonia protoparmeliopsidis, Lichenostigma radicans, L. subradians and Sclerococcum sphaerale-represent new records for Turkey. In addition, A. protoparmeliopsidis is new to Asia and Gemmaspora lecanorae was found for the second time on Aspicilia sp. Geographical distributions are also presented.
\end{abstract}

Key words: Ascomycetes, lichens, new records, taxonomy

\section{Introduction}

Although lichenicolous fungi of Turkey have been the subject of a number of recent studies (Candan \& Halici 2009; Etayo \& Yazici 2009; Yazici et al. 2010a, 2010b, 2010c; Yazici et al. 2011a, 2011b, 2012; Halici et al. 2010, 2012; Halici \& Aksoy 2009), knowledge of such fungi is still insufficient. To date, 139 lichenicolous fungal taxa have been found in Turkey (Yazici et al. 2011b). This number is small when compared with those of some better studied European countries (Fałtynowicz 2003; Hawksworth 2003; Hawksworth \& Cole 2002; Kocourková 2000; Santesson et al. 2004; Scholz 2000). Therefore, additional studies are needed in order to increase the knowledge of lichenicolous fungi in Turkey.

No lichenicolous fungi have thus far been reported for the Iğdır province, although 14 lichens have been recorded for the region (Aptroot \& Yazici 2012; Vondrák et al. 2012; Yazici et al. 2012; Yazici et al. 2011c). In this paper, we report four lichenicolous fungi that represent new records for the Iğdır region and for Turkey.

\section{Material and methods}

\section{Collection sites}

During lichenological field studies carried out between 28 March 2010 and 14 June 2011, specimens were collected from 41 sites within the Iğdır region (Tab. 1). Lichenicolous fungi species were collected from an area near the capital city of Iğdır (central Iğdır province), as well as from the districts of Tuzluca, Aralık, Karakoyunlu (Fig. 1). The province of Iğdır is in eastern Turkey, bordering Armenia, Nakhchivan and Iran. The adjacent provinces are Kars to the northwest and Ağrı to the west and south. Iğdır occupies an area of $3587 \mathrm{~km}^{2}$ and has a population of 184,418 (Fig. 1).

The Iğdır province, where the vegetation is comprised primarily of grassy plants, is one of several poorly forested areas of mainly steppe in Turkey. In northern and southeastern Iğdır, in the Karakoyunlu and Aralık districts, as well as to the north and east of the Tuzluca district, there are many treeless grassy plains. The area is sunny, windswept and open. The gently sloping terrain features streams and grassy areas, with calcareous and siliceous rocks. Some of the mountains, including Ağrı, Zordağ, Tekaltt, Oyuklu and Ziyaret, which are exposed to intense light conditions, are also dominated by grass, rocks (siliceous and calcareous) and streams, with scattered coniferous and deciduous trees, such as Elaeagnus, Populus, Prunus, Pyrus and Salix (Baytop \& Denizci 1963).

According to Baytop \& Denizci (1963), Prunus, Pyrus, Populus, Salix, and Elaeagnus trees occur occasionally along the streams in many villages, such as Köprübaşı and Sürmeli (in the Tuzluca district); Saraçlı, Aşağı Çamurlu, Hasanhan, Babacan and Aşağı Topraklı (in the Aralık district); and Gökçeli, Cennetabat and Bayatdoğanşalı (in the Karakoyunlu district). Calcareous and siliceous rocks are seen in many villages in the southern parts of the Iğdır region. Very few lichen and lichenicolous fungi species were seen in some villages, especially along Aras River, which forms the border with Armenia in the north of Iğdır.

In the villages of Bulakbaşı, Yazlık, Aktaş, İslamköy and Adetli, located on the northern slopes of Ağrı Mountain,

\footnotetext{
${ }^{1}$ Karadeniz Technical University, Faculty of Science, Department of Biology, Trabzon, Turkey

${ }^{2}$ Navarro Villoslada, Pamplona, Navarra, Spain

${ }^{3}$ Author Corrresponding: kenanyazici_1965@yahoo.com
} 
Table 1. Collection sites in Iğdır province, Turkey.

\begin{tabular}{|c|c|c|c|c|}
\hline No. & District: site & Coordinates & Altitude $(\mathrm{m})$ & Date \\
\hline 1 & Iğdır: alongside the main Iğdır-Doğubeyazıt road (12 km from Iğdır city) & $\begin{array}{l}39^{\circ} 50^{\prime} 43.69^{\prime \prime} \mathrm{N} \\
44^{\circ} 04^{\prime} 43.70^{\prime \prime} \mathrm{E}\end{array}$ & 914 & 28 Mar., 2010 \\
\hline 2 & $\begin{array}{l}\text { Iğdır: center, } 10 \mathrm{~km} \text { west of Iğdır, } 16 \mathrm{~km} \text { in from the Yukarı Çarıkçı village turnoff, on the } \\
\text { roadside, in Hoşhaber village }\end{array}$ & $\begin{array}{l}39^{\circ} 51^{\prime} 56.08^{\prime \prime} \mathrm{N} \\
43^{\circ} 56^{\prime} 52.60^{\prime \prime} \mathrm{E}\end{array}$ & 1181 & 29 Mar., 2010 \\
\hline 3 & Iğdır: Bendemurat village & $\begin{array}{l}39^{\circ} 47^{\prime} 16.06^{\prime \prime} \mathrm{N} \\
43^{\circ} 57^{\prime} 30.14^{\prime \prime} \mathrm{E}\end{array}$ & 2121 & 16 Jul., 2010 \\
\hline 4 & Iğdır: Gülpınar village & $\begin{array}{l}39^{\circ} 47^{\prime} 17.30^{\prime \prime} \mathrm{N} \\
44^{\circ} 00^{\prime} 41.35^{\prime \prime} \mathrm{E}\end{array}$ & 1609 & 16 Jul., 2010 \\
\hline 5 & Iğdır: South of Halfeli & $\begin{array}{l}39^{\circ} 52^{\prime} 32.84^{\prime \prime} \mathrm{N} \\
43^{\circ} 57^{\prime} 28.53^{\prime \prime} \mathrm{E}\end{array}$ & 1028 & 29 Mar., 2010 \\
\hline 6 & Iğdır: Korhan plateau, roadside (hillside of Ağrı Mountain) & $\begin{array}{l}39^{\circ} 47^{\prime} 46.07^{\prime \prime} \mathrm{N} \\
44^{\circ} 14^{\prime} 10.72^{\prime \prime} \mathrm{E}\end{array}$ & 2072 & 28 Mar., 2010 \\
\hline 7 & Iğdır: Örüşmüş village & $\begin{array}{l}39^{\circ} 47^{\prime} 36.03^{\prime \prime} \mathrm{N} \\
43^{\circ} 58^{\prime} 16.84 " \mathrm{E}\end{array}$ & 1945 & 16 Jul., 2010 \\
\hline 8 & Iğdır: Pınarbaşı Köyü village & $\begin{array}{l}39^{\circ} 49^{\prime} 08.37^{\prime \prime} \mathrm{N} \\
43^{\circ} 47^{\prime} 08.97^{\prime \prime} \mathrm{E}\end{array}$ & 1843 & 13 Jul., 2010 \\
\hline 9 & Iğdır: Taşlıca village & $\begin{array}{l}39^{\circ} 50^{\prime} 00.37^{\prime \prime} \mathrm{N} \\
43^{\circ} 47^{\prime} 48.56^{\prime \prime} \mathrm{E}\end{array}$ & 1704 & 13 Jul., 2010 \\
\hline 10 & Iğdır: Zor Mountain & $\begin{array}{l}39^{\circ} 45^{\prime} 49.05^{\prime \prime} \mathrm{N} \\
43^{\circ} 53^{\prime} 20.13^{\prime \prime} \mathrm{E}\end{array}$ & 2400 & 13 Jun., 2010 \\
\hline 11 & Iğdır: Asma village & $\begin{array}{l}39^{\circ} 47^{\prime} 49.70^{\prime \prime} \mathrm{N} \\
43^{\circ} 48^{\prime} 35.53^{\prime \prime} \mathrm{E}\end{array}$ & 1868 & 13 Jul., 2010 \\
\hline 12 & Aralık: Bilican village & $\begin{array}{l}39^{\circ} 41^{\prime} 12.81^{\prime \prime} \mathrm{N} \\
44^{\circ} 24^{\prime} 16.11^{\prime \prime} \mathrm{E}\end{array}$ & 2320 & 14 Jun., 2011 \\
\hline 13 & Aralık: Gömük village & $\begin{array}{l}39^{\circ} 42^{\prime} 17.36^{\prime \prime} \mathrm{N} \\
44^{\circ} 24^{\prime} 13.63^{\prime \prime} \mathrm{E}\end{array}$ & 2198 & 14 Jun., 2011 \\
\hline 14 & Aralık: Tarlabaşı village & $\begin{array}{l}39^{\circ} 474^{\prime} 4.22^{\prime \prime} \mathrm{N} \\
44^{\circ} 24^{\prime} 17.25^{\prime \prime} \mathrm{E}\end{array}$ & 1421 & 14 Jun., 2011 \\
\hline 15 & Aralık: between the villages of Karakoyunlu and Melekli, $200-250 \mathrm{~m}$ off the main road & $\begin{array}{l}39^{\circ} 57^{\prime} 30.50^{\prime \prime} \mathrm{N} \\
44^{\circ} 08^{\prime} 58.02^{\prime \prime} \mathrm{E}\end{array}$ & 860 & 30 Mar., 2010 \\
\hline 16 & Karakoyunlu: Taşburun village, $300 \mathrm{~m}$ off the main road & $\begin{array}{l}39^{\circ} 58^{\prime} 01.68^{\prime \prime} \mathrm{N} \\
44^{\circ} 14^{\prime} 08.40^{\prime \prime} \mathrm{E}\end{array}$ & 860 & 30 Mar., 2010 \\
\hline 17 & Karakoyunlu: Aktaş village & $\begin{array}{l}39^{\circ} 55^{\prime} 09.12^{\prime \prime} \mathrm{N} \\
44^{\circ} 16^{\prime} 04.34^{\prime \prime} \mathrm{E}\end{array}$ & 828 & 14 Jun., 2011 \\
\hline 18 & Karakoyunlu: Yazlık village & $\begin{array}{l}39^{\circ} 54^{\prime} 38.48^{\prime \prime} \mathrm{N} \\
44^{\circ} 16^{\prime} 53.91^{\prime \prime} \mathrm{E}\end{array}$ & 830 & 14 Jun., 2011 \\
\hline 19 & Karakoyunlu: Korhan plateau (area surrounding the gendarmerie headquarters) & $\begin{array}{l}39^{\circ} 47^{\prime} 11.09^{\prime \prime} \mathrm{N} \\
44^{\circ} 16^{\prime} 06.73^{\prime \prime} \mathrm{E}\end{array}$ & 1904 & 17 Jun., 2010 \\
\hline 20 & Karakoyunlu: Ağrı Mountain & $\begin{array}{c}39^{\circ} 45^{\prime} 18.86^{\prime \prime} \mathrm{N} \\
44^{\circ} 16^{\prime} 12.52^{\prime \prime} \mathrm{E}\end{array}$ & 3191 & 29 Jul., 2011 \\
\hline 21 & Karakoyunlu: Bulakbaşı village & $\begin{array}{c}39^{\circ} 56^{\prime} 13.89^{\prime \prime} \mathrm{N} \\
44^{\circ} 15^{\prime} 30.49^{\prime \prime} \mathrm{E}\end{array}$ & 832 & 14 Jun., 2011 \\
\hline 22 & Tuzluca: Taşucan village & $\begin{array}{l}39^{\circ} 51^{\prime} 26.61^{\prime \prime} \mathrm{N} \\
43^{\circ} 35^{\prime} 41.06^{\prime \prime} \mathrm{E}\end{array}$ & 3168 & 2 Jul., 2010 \\
\hline 23 & Tuzluca: between the villages of Yukarı Civanlı and Aşağı Civanlı & $\begin{array}{l}40^{\circ} 00^{\prime} 31.57^{\prime \prime} \mathrm{N} \\
43^{\circ} 32^{\prime} 526.37^{\prime \prime} \mathrm{E}\end{array}$ & 1882 & 16 Jun., 2010 \\
\hline 24 & Tuzluca: Aşağı Aktaş village (monument tomb and roadside) & $\begin{array}{l}40^{\circ} 04^{\prime} 45.42^{\prime \prime} \mathrm{N} \\
43^{\circ} 31^{\prime} 34.61^{\prime \prime} \mathrm{E}\end{array}$ & 1538 & 5 Jul., 2010 \\
\hline 25 & Tuzluca: Bahçelimeydan village & $\begin{array}{l}40^{\circ} 03^{\prime} 50.07^{\prime \prime} \mathrm{N} \\
43^{\circ} 27^{\prime} 01.70^{\prime \prime} \mathrm{E}\end{array}$ & 1328 & 12 Jul., 2010 \\
\hline 26 & Tuzluca: Güllüce village & $\begin{array}{c}39^{\circ} 53^{\prime} 29.26^{\prime \prime} \mathrm{N} \\
43^{\circ} 39^{\prime} 33.47^{\prime \prime} \mathrm{E}\end{array}$ & 1769 & 15 Jun., 2010 \\
\hline 27 & Tuzluca: Gaziler village & $\begin{array}{l}40^{\circ} 05^{\prime} 02.40^{\prime \prime} \mathrm{N} \\
43^{\circ} 26^{\prime} 55.40^{\prime \prime} \mathrm{E}\end{array}$ & 1116 & 3 Jul., 2010 \\
\hline
\end{tabular}


Table 1. Continuation

\begin{tabular}{|c|c|c|c|c|}
\hline No. & District: site & Coordinates & Altitude (m) & Date \\
\hline 28 & Tuzluca: Tekaltı Mountain & $\begin{array}{l}40^{\circ} 01^{\prime} 57.22^{\prime \prime} \mathrm{N} \\
43^{\circ} 33^{\prime} 12.89^{\prime \prime} \mathrm{E}\end{array}$ & 2257 & 4 Jul., 2010 \\
\hline 29 & $\begin{array}{l}\text { Tuzluca: on the Tuzluca-Kağızman border, alongside the main road, at the Aşağı Aktaş village } \\
\text { turnoff }\end{array}$ & $\begin{array}{l}40^{\circ} 06^{\prime} 27.27^{\prime \prime} \mathrm{N} \\
43^{\circ} 30^{\prime} 16.05^{\prime \prime} \mathrm{E}\end{array}$ & 1055 & 31 Mar., 2010 \\
\hline 30 & Tuzluca: along the roadside in the villages of Bahçecik and Bahçeçik & $\begin{array}{l}40^{\circ} 04^{\prime} 05.63^{\prime \prime} \mathrm{N} \\
43^{\circ} 25^{\prime} 35.47^{\prime \prime} \mathrm{E} \\
40^{\circ} 04^{\prime} 27.27^{\prime \prime} \mathrm{N} \\
43^{\circ} 25^{\prime} 06.12^{\prime \prime} \mathrm{E}\end{array}$ & 1693,1754 & 12 Jul., 2010 \\
\hline 31 & Tuzluca: İnceköy village & $\begin{array}{l}39^{\circ} 53^{\prime} 17.06^{\prime \prime} \mathrm{N} \\
43^{\circ} 38^{\prime} 09.44^{\prime \prime} \mathrm{E}\end{array}$ & 1777 & 2 Jul., 2010 \\
\hline 32 & Tuzluca: between the villages of Uğurca and Yukarı Civanlı & $\begin{array}{l}40^{\circ} 00^{\prime} 03.72^{\prime \prime} \mathrm{N} \\
43^{\circ} 26^{\prime} 25.80^{\prime \prime} \mathrm{E}\end{array}$ & 2056 & 16 Jun., 2010 \\
\hline 33 & Tuzluca: Göktaş village, roadside & $\begin{array}{l}39^{\circ} 59^{\prime} 52.55^{\prime \prime} \mathrm{N} \\
43^{\circ} 33^{\prime} 55.78^{\prime \prime} \mathrm{E}\end{array}$ & 1489 & 16 Jun., 2010 \\
\hline 34 & Tuzluca: $1 \mathrm{~km}$ from Çıraklı village, roadside & $\begin{array}{l}40^{\circ} 03^{\prime} 53.89^{\prime \prime} \mathrm{N} \\
43^{\circ} 29^{\prime} 32.98^{\prime \prime} \mathrm{E}\end{array}$ & 1428,1571 & 3 Jul., 2010 \\
\hline 35 & Tuzluca: between the villages of Ağaçlı and Bağlan, roadside & $\begin{array}{c}39^{\circ} 54^{\prime} 51.67^{\prime \prime} \mathrm{N} \\
43^{\circ} 39^{\prime} 07.05^{\prime \prime} \mathrm{E}\end{array}$ & 1727 & 2 Jul., 2010 \\
\hline 36 & Tuzluca: between the villages of Taşköprü and Karacaköyü & $\begin{array}{c}39^{\circ} 52^{\prime} 07.40^{\prime \prime} \mathrm{N} \\
43^{\circ} 28^{\prime} 50.94^{\prime \prime} \mathrm{E}\end{array}$ & 2134 & 14 Jun., 2010 \\
\hline 37 & Tuzluca: $2 \mathrm{~km}$ from Canderviş village, roadside & $\begin{array}{c}39^{\circ} 56^{\prime} 23.67^{\prime \prime} \mathrm{N} \\
43^{\circ} 30^{\prime} 09.63^{\prime \prime} \mathrm{E}\end{array}$ & 2189 & 16 Jun., 2010 \\
\hline 38 & Tuzluca: Ünlendi village & $\begin{array}{c}39^{\circ} 53^{\prime} 49.48^{\prime \prime} \mathrm{N} \\
43^{\circ} 33^{\prime} 38.86^{\prime \prime} \mathrm{E}\end{array}$ & 1949 & 14 Jun., 2010 \\
\hline 39 & Tuzluca: $3 \mathrm{~km}$ from Taşköprü village and $3 \mathrm{~km}$ from Kandilli village, roadside & $\begin{array}{l}39^{\circ} 51^{\prime} 25.16^{\prime \prime} \mathrm{N} \\
43^{\circ} 27^{\prime} 33.13^{\prime \prime} \mathrm{E}\end{array}$ & 2240 & 14 Jun., 2010 \\
\hline 40 & Tuzluca: Kula village, roadside & $\begin{array}{l}40^{\circ} 51^{\prime} 4.25^{\prime \prime} \mathrm{N} \\
43^{\circ} 25^{\prime} 53.48^{\prime \prime} \mathrm{E}\end{array}$ & 1175 & 12 Jul., 2010 \\
\hline 41 & Tuzluca: Ziyaret Mountain & $\begin{array}{c}40^{\circ} 02^{\prime} 51.06^{\prime \prime} \mathrm{N} \\
43^{\circ} 24^{\prime} 33.22^{\prime \prime} \mathrm{E}\end{array}$ & 2101 & 24 Jun., 2011 \\
\hline
\end{tabular}

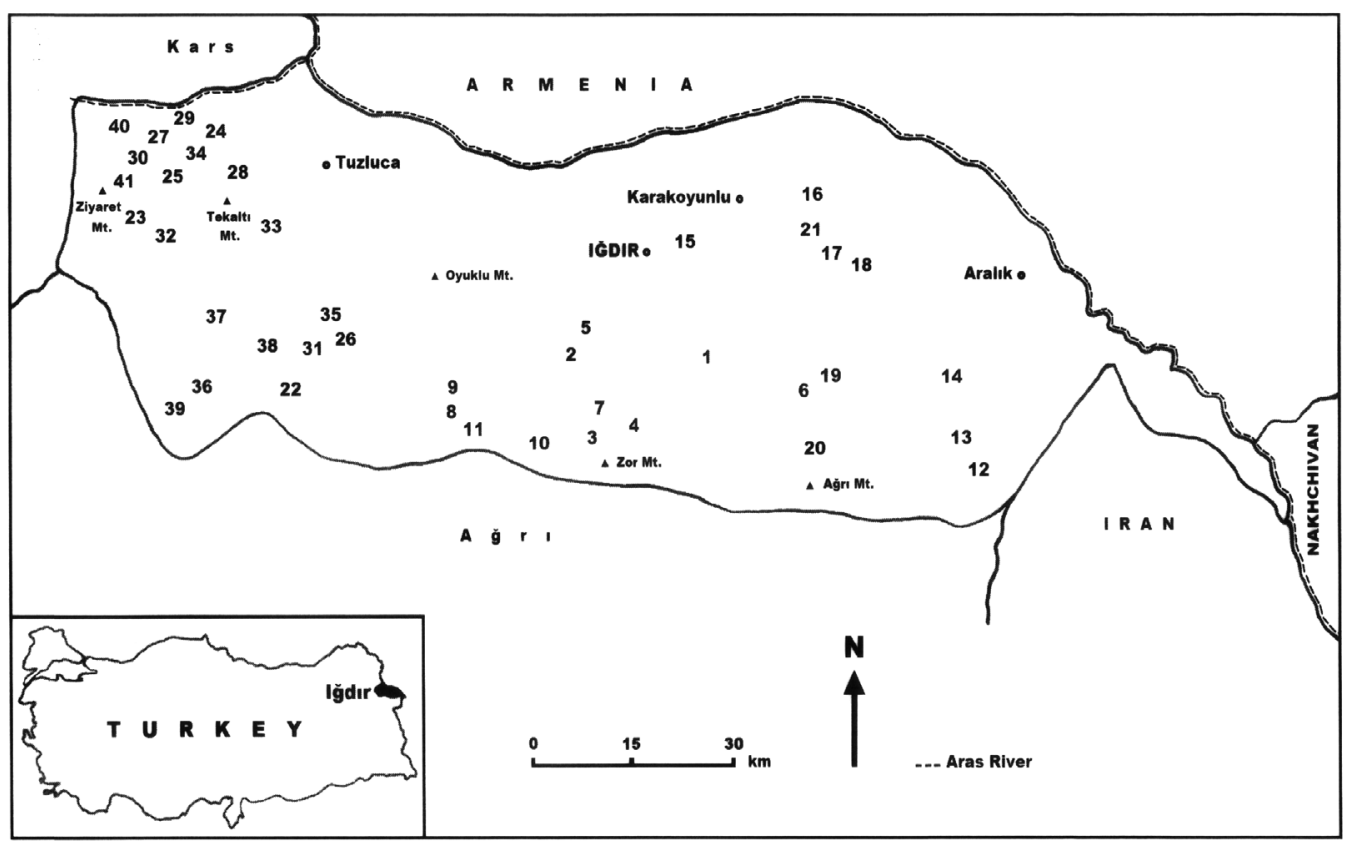

Figure 1. Map of Iğdır province (Turkey), showing the sites* at which lichenicolous fungi were collected. ${ }^{*}$ Numbering corresponds to Tab. 1. 
there are few deciduous or coniferous trees. In those villages, especially those on the Korhan plateau, the rocks are predominantly volcanic. At an elevation of 2000-3200 m, we observed mostly crustose lichens on volcanic rocks. On the Korhan plateau, the tree population is very poor, comprising only certain deciduous trees, such as Betula and Populus. Therefore, the population of lichen and lichenicolous fungi on the body of trees is poor, with little biodiversity.

The climate in the Iğdır region is characterized by hot, dry summers and cold, snowy winters. The mean annual temperature is $11.6^{\circ} \mathrm{C}$, with a mean annual humidity of $63 \%$ and a mean annual rainfall of $257.6 \mathrm{~mm}$ (Akman 1999).

\section{Collection, storage and processing of samples}

Hand-cut sections were microscopically examined in water (including all measurements), 10\% potassium hydroxide or lactophenol cotton blue. Air-dried samples were observed and studied with a Nikon SMZ1500 stereomicroscope and a Nikon Eclipse 80i light microscope (Nikon, Tokyo, Japan). Descriptions of the species are based on the materials collected from the area and on data in the literature. Nomenclature and species concepts follow Atienza et al. (2003), Hawksworth (2003), Santesson et al. (2004), Halici et al. (2007), Etayo \& Sancho (2008), Etayo \& Navarro-Rosinés (2008) and Navarro-Rosinés et al. (2009). Voucher specimens were stored in the Herbarium of the Biology Department, Faculty of Science, Karadeniz Technical University, Trabzon, Turkey (KTUB).

\section{Results}

\section{Within the study area, we identified the following species:}

Arthonia clemens (Tul.) Th. Fr. - Iğdır: [Loc. 10], (KTUB 2357); [Loc. 32], (KTUB 2354); [Loc. 38], (KTUB 2356), on the apothecia of Rhizoplaca chrysoleuca.

Arthonia epiphyscia Nyl. - Iğdır: [Loc. 11], (KTUB 2116), on the thallus of Physcia dubia; [Loc. 2], (KTUB 2119); [Loc. 23], (KTUB 2111); [Loc. 22], (KTUB 2118); [Loc. 30], (KTUB 2104), on the thalli of Physcia biziana.

Arthonia hawksworthii Halici - Iğdır: [Loc. 20], (KTUB 2106); [Loc. 9], (KTUB 2220), on the thallus of Dimelaena oreina.

Arthonia molendoi (Heufl. ex Frauenf.) R. Sant. - Iğdır: [Loc. 29], (KTUB 2112); [Loc. 18], (KTUB 2115); [Loc. 30], (KTUB 2113); [Loc. 21], (KTUB 2117); [Loc. 12], (KTUB 2223), on the thalli and apothecia of Xanthoria elegans.

Arthonia phaeophysciae Grube \& Matzer - Iğdır [Loc. 20], (KTUB 2225), on the thallus of Phaeophyscia sciastra. Arthonia protoparmeliopsidis Etayo \& Diederich - Iğdır: [Loc. 32], (KTUB 2114), on the discs of apothecia of Lecanora muralis; mixed with Cercidospora macrospora. This species was described in detail by Etayo \& Diederich (2009). Previously known from Spain and Luxembourg. New to Turkey and Asia. Ascomata single or grouped, large and blackish, roughly convex, round or irregular in shape, immersed in the thallus or apothecial discs; asci 8-spored, claviform or ellipsoid, wall thickened with an ocular chamber, 22.0-42.0 × 10.0-15.0 $\mu \mathrm{m}$; ascospores 2- to 3-septate, ellipsoid, colorless, thin-walled, slightly constricted at the septa, perispore thin, 10.0-15.0 $\times 3.5-6.0 \mu \mathrm{m}$. Hymenium pale brown, I+ red, 45.0-50.0 $\mu \mathrm{m}$ tall. Epihymenium brown or olive brown, $\mathrm{K}+$ olive-green.

Caloplaca grimmiae (Nyl.) H. Olivier - Iğdır: [Loc. 6], (KTUB 2107); [Loc. 1], (KTUB 2110); [Loc. 10], (KTUB 2221); [Loc. 7], (KTUB 2109); [Loc. 4], (KTUB 2108); [Loc. 3], (KTUB 2222); [Loc. 12], (KTUB 2224); [Loc. 14], (KTUB 2108); [Loc. 21], (KTUB 2119); [Loc. 18], (KTUB 2228); [Loc. 17], (KTUB 2226); [Loc. 20], (KTUB 2229); [Loc. 38], (KTUB 2230); [Loc. 32], (KTUB 2237); [Loc. 23], (KTUB 2233); [Loc. 33], (KTUB 2227); [Loc. 41], (KTUB 2231); [Loc. 31], (KTUB 2245); [Loc. 37], (KTUB 2240); [Loc. 30], (KTUB 2232); [Loc. 40], (KTUB 2236); [Loc. 28], (KTUB 2238), on the thalli of Candelariella vitellina.

Carbonea supersparsa (Nyl.) Hertel - Iğdır: [Loc. 1], (KTUB 2234), on the thallus of Lecanora polytropa.

Carbonea vitellinaria (Nyl.) Hertel - Iğdır: [Loc. 11], (KTUB 2239); [Loc. 12], (KTUB 2241); [Loc. 13], (KTUB 2235); [Loc. 19], (KTUB 2243); [Loc. 38], (KTUB 2250); [Loc. 36], (KTUB 2242); [Loc. 39], (KTUB 2247); [Loc. 32], (KTUB 2246); [Loc. 22], (KTUB 2249); [Loc. 35], (KTUB 2248); [Loc. 30], (KTUB 2244), on the thalli of Candelariella vitellina.

Carbonea vorticosa (Flörke) Hertel - Iğdır: [Loc. 1], (KTUB 2254), on the thallus of Lecidella sp. Recorded for the second time in Turkey.

Cercidospora caudata Kernst. - Iğdır: [Loc. 36], (KTUB 2251), on the thallus and apothecia of Caloplaca conversa. Cercidospora macrospora (Uloth) Hafellner \& Nav.-Ros. - Iğdır: [Loc. 32], (KTUB 2253); [Loc. 33], (KTUB 2256); [Loc. 30], (KTUB 2252); [Loc. 7], (KTUB 2268); [Loc. 6], (KTUB 2259); [Loc. 34], (KTUB 2267), on the thalli and apothecia of Lecanora muralis.

Cercidospora melanophthalmae Nav.-Ros., Calat. \& Hafellner - Iğdır: [Loc. 10], (KTUB 2261); [Loc. 38], (KTUB 2255), on the thalli and apothecia of Rhizoplaca melanophthalma. Second record for Turkey.

Cercidospora solearispora Calat., Nav.-Ros. \& Hafellner Iğdır: [Loc. 34], (KTUB 2260), on the thallus of Aspicilia cinerea and Lecanora muralis. This species is characterized by its caudate spores with strongly heteropolar septum, 20.0-26.0 $\times 6.0-6.5 \mu \mathrm{m}$, was previously reported for Turkey by Halici et al. (2007). Second record for Turkey.

Cercidospora xanthoriae (Wedd.) R. Sant. - Iğdır: [Loc. 29], (KTUB 2266); [Loc. 30], (KTUB 2263), on the thalli and apothecia of Xanthoria elegans. Asci mostly 4-spored; ascospores not heteropolar, pointed at the ends, 23.0-27.0 $\times 5.5-7.0 \mu \mathrm{m}$. 
Dactylospora saxatilis (Schaer.) Hafellner - Iğdır: [Loc. 28], (KTUB 2269); [Loc. 27], (KTUB 2264); [Loc. 20], (KTUB 2270); [Loc. 35], (KTUB 2258), on the thalli of Pertusaria flavicans.

Echinothecium reticulatum Zopf - Iğdır: [Loc. 13], (KTUB 2271); [Loc. 2], (KTUB 2257), on the thalli of Parmelia saxatilis.

Endococcus macrosporus (Hepp ex Arnold) Nyl. - Iğdır: [Loc. 28], (KTUB 2265); [Loc. 31], (KTUB 2262), on the thalli of Rhizocarpon geographicum.

Endococcus rugulosus Nyl. - Iğdır: [Loc. 19], (KTUB 2276), on the thallus of Buellia sequax.

Endococcus stigma (Körb.) Stizenb. - Iğdır: [Loc. 13], (KTUB 2272), on the thallus of Acarospora sp.

Endohyalina insularis (Arnold) Giralt, Van den Boom \& Elix - Iğdır: [Loc. 27], (KTUB 2274), on the thallus of Lecanora rupicola.

Gemmaspora lecanorae (Werner) D. Hawksw. \& Halici Iğdır: [Loc. 21], (KTUB 2275); [Loc. 8], (KTUB 2280), on the thalli of Aspicilia sp. This genus was first described by Werner (1964). G. lecanorae was reported for the first time on the thalli of Aspicilia cf. farinosa and A. calcarea for Turkey by Hawksworth \& Halici (2007) and was found for the second time on Aspicilia sp. in this study.

Intralichen lichenicola (M. S. Christ. \& D. Hawksw.) D. Hawksw. \& M. S. Cole - Iğdır: [Loc. 20], (KTUB 2273), on the thallus and apothecia of Candelariella vitellina, [Loc. 36], (KTUB 2277), on the thallus of Caloplaca conversa.

Intralichen christiansenii (D. Hawksw.) D. Hawksw. \& M.S. Cole - Iğdır: [Loc. 36], (KTUB 2279), on the thallus of Caloplaca conversa.

Lichenoconium lecanorae (Jaap) D. Hawksw. - Iğdır: [Loc. 2], (KTUB 2278), on the thallus of Rhizoplaca chrysoleuca.

Lichenostigma dimelaenae Calat. \& Hafellner - Iğdır: [Loc. 38], (KTUB 2284); [Loc. 8], (KTUB 2281); [Loc. 12], (KTUB 2285); [Loc. 39], (KTUB 2282); [Loc. 32], (KTUB 2290); [Loc. 29], (KTUB 2288); [Loc. 20], (KTUB 2286); [Loc. 25], (KTUB 2283); [Loc. 21], (KTUB 2289); [Loc. 5], (KTUB 2291), on the thalli of Dimelaena oreina.

Lichenostigma elongatum Nav.-Ros. \& Hafellner - Iğdır: [Loc. 21], (KTUB 2297); [Loc. 15], (KTUB 2293); [Loc. 21], on the thalli of Aspicilia caesiocinerea; [Loc. 16], (KTUB 2287); [Loc. 2], (KTUB 2294); [Loc. 34], (KTUB 2292); [Loc. 32], (KTUB 2296); [Loc. 17], (KTUB 2295); [Loc. 18], (KTUB 2298); [Loc. 27], (KTUB 2300), on the thalli of Aspicilia cinerea.

Lichenostigma rugosum $\mathrm{G}$. Thor - Iğdır: [Loc. 32], (KTUB 2310), on the thallus of Diploschistes muscorum.
Lichenostigma radicans Calat. \& Barreno - Iğdır: [Loc. 32], (KTUB 2304), on the thallus of Aspicilia sp. This species was described in detail by Calatayud \& Barreno (2003). Previously known from Spain and North America. New to Turkey. Ascomata blackish, scarce or 2-6 ascomata in group, mostly immersed in the host thallus, rounded, $\leq 70.0 \mu \mathrm{m}$ tall, $\leq 165.0 \mu \mathrm{m}$ wide; upper part mostly smooth; lower part usually penetrating downwards into the host thallus. Internal structure stromatic, paraplectenchymatous, 5.0-7.5 $\mu \mathrm{m}$ diam. Asci 8-spored, fissitunicate, subglobose, ca. 17.0$20.0(-2.0) \mu \mathrm{m}$ high, $12.5-14.5 \mu \mathrm{m}$ wide; ascospores brown, 1-septate, obovate, with rounded apices, constricted at the septum, oldest with a verruculose surface, 10.0-13.0(-14.0) $\times 5.0-7.0(-7.5) \mu \mathrm{m}$. Anamorph unknown.

Lichenostigma subradians Hafellner, Calat. \& Nav.-Ros. - Iğdır: [Loc. 17], (KTUB 2302); [Loc. 24], (KTUB 2306), on the thalli of Acarospora sp. This species was described in detail by Calatayud et al. (2002). Previously known from the United States (state of Arizona), Saudi Arabia, the Canary Islands and Mexico. New to Turkey. Ascomata black, superficial, mostly elongated, each radiating a black strand of vegetative hyphae on the surface of the host, usually adpressed with a main axis showing a few short lateral branches; main strands composed of 2-4 rows of cells, lateral branches composed of 1-2 rows of cells. Additional vegetative hyphae penetrating into the host thallus, hyaline. Asci 8-spored, multiple, fissitunicate, subglobose or broadly obovate, 25.0-30.0 $\times 18.0-25.0 \mu \mathrm{m}$; ascospores 1-septate, ellipsoid or obovate, with rounded apices, slightly constricted at the septum, pale brown, with a granular surface when mature, 9.0-10.0(-11.0) $\times(5.0-) 5.5-6.5 \mu \mathrm{m}$. Anamorph unknown.

Lichenostigma triseptatum Halıcı \& D. Hawksw. - Iğdır: [Loc. 1], (KTUB 2308), on the thallus of Aspicilia caesiocinerea.

Muellerella erratica (A. Massal.) Hafellner \& V. John Iğdır: [Loc. 31], (KTUB 2305), on the thallus of Lecanora sp.; [Loc. 27], (KTUB 2303); [Loc. 21], (KTUB 2307); [Loc. 10], (KTUB 2301); [Loc. 7], (KTUB 2299), on the thalli of Aspicilia spp.; [Loc. 3], (KTUB 2311), on the thallus of Lecidella sp.; [Loc. 28], (KTUB 2309); [Loc. 24], (KTUB 2315), on the thalli of Acarospora sp.; [Loc. 36], (KTUB 2312), on the thallus of Lecidea sp.

Muellerella pygmaea (Körb.) D. Hawksw. - Iğdır: [Loc. 29], (KTUB 2320); [Loc. 2], (KTUB 2314); [Loc 34.], (KTUB 2313); [Loc. 27], (KTUB 2318); [Loc. 21], (KTUB 2316); [Loc. 30], (KTUB 2319); [Loc. 28], (KTUB 2322), on the thalli of Acarospora sp.; [Loc. 10], (KTUB 2317), on the thallus of Lecidea fuscoatra. Ascus 32-spored, sometimes only 8-spored, little more brown, when young hyaline and simple, verruculose surface, 9.0-12.0 × 5.5-7.0 $\mu \mathrm{m}$, much larger than normal.

Muellerella ventosicola (Mudd) D. Hawksw. - Iğdır: [Loc. 29], (KTUB 2329), on the thallus of Rhizocarpon geographicum. 
Polycoccum evae Calat. \& V.J. Rico - Iğdır: [Loc. 35], (KTUB 2328); [Loc. 11], (KTUB 2330); [Loc. 4], (KTUB 2324); [Loc. 2], (KTUB 2327); [Loc. 25], (KTUB 2325), on the thalli of Dimelaena oreina.

Sclerococcum sphaerale (Ach.) Fr. - Iğdır: [Loc. 6], (KTUB 2326), on the thallus of Pertusaria sp. This species was described in detail by Hawkswoth \& Jones (1981). Previously known from Austria, Czech Republic, Luxembourg, Spain and Portugal. New to Turkey. Sporodochia black, in spherical or hemispherical tufts, $170.0-350.0 \mu \mathrm{m}$, suppressing the formation of isidia on the host thallus of Pertusaria sp. Under microscopy, conidia thick and even walled, without fissures or thickened parts, thick-walled cells with dark walls. Mostly 6.0-10.0 $\mu \mathrm{m}$ in diameter.

Stigmidium tabacinae (Arnold) Triebel - Iğdır: [Loc. 27], (KTUB 2355), on the thallus of Toninia sedifolia.

Tetramelas pulverulentus (Anzi) A. Nordin \& Tibell - Iğdır: [Loc. 26], (KTUB 2323), on the thallus of Physcia dubia.

Zwackhiomyces cervinae Calat., Triebel \& Pérez-Ortega Iğdır: [Loc. 13], (KTUB 2333), on the thallus of Acarospora sp.

Zwackhiomyces coepulonus (Norman) Grube \& R. Sant. Iğdır: [Loc. 40], (KTUB 2321); [Loc. 14], (KTUB 2331), on the thalli of Caloplaca lobulata; [Loc. 18], (KTUB 2332); [Loc. 29], (KTUB 2334), in the apothecia of Xanthoria elegans. Conidiomata with conidiogenous cells, $10-15 \times 1-1.5$ $\mu \mathrm{m}$ and bacilliform conidia, 2.0-3.5 $\times 0.5 \mu \mathrm{m}$.

\section{Discussion}

All lichenicolous fungi were collected on foliose and crustose lichens. Only one species of lichenicolous fungi was found on the host genera Buellia, Diploschistes, Lecidea, Lecidella, Parmelia, Phaeophyscia and Toninia, whereas we found two species on Pertusaria, Rhizocarpon and Rhizoplaca; three species on Caloplaca, Physcia, Candelariella vitellina, Dimelaena oreina and Xanthoria elegans; five species on Acarospora; six species on Lecanora (Lecanora sp., L. muralis, L. rupicola and L. polytropa); and seven species on Aspicilia.

Arthonia molendoi, A. protoparmeliopsidis, Cercidospora caudata, C. macrospora, C. melanophthalmae, C. xanthoriae, Intralichen lichenicola, Zwackhiomyces coepulonus were found on the thallus and apothecia of foliose and crustose species; 27 other species were found only on the thallus of crustose lichenized fungi; and 4 species were found only on the thallus of foliose lichens.

The most common genera of lichenicolous fungi identified were Lichenostigma, Cercidospora and Arthonia, and the most common species were Caloplaca grimmiae, Carbonea vitellinaria, Cercidospora macrospora, Lichenostigma dime- laenae, L. elongatum, Muellerella erratica and M. pygmaea. We found eight lichenicolous fungi at sites 21 and 32; seven species at site 30; and six species at sites 2, 20 and 29. The host preference of lichenicolous fungi, especially that of those representing new records, was found to be largely identical to that reported in the literature (Hawksworth 2003; Etayo \& Sancho 2008; Halici 2008).

It is of note that all samples were found on the host thalli of 26 different crustose or foliose lichens, collected mostly from rocks. Although the Iğdır province is one of the poorest regions of Turkey, in terms of the amount of forest cover, and is dominated by steppe, the lichenicolous biodiversity was moderately rich. This might be attributable to the Mediterranean climate of the area.

All of the species of lichenicolous fungi listed here represent new records for the Iğdır region, and four (Arthonia protoparmeliopsidis, Lichenostigma radicans, Lichenostigma subradians and Sclerococcum sphaerale) are new to Turkey. In addition, A. protoparmeliopsidis is new to Asia.

\section{Acknowledgments}

We are grateful to Dr. Jurga Motiejunaite and Dr. Mikhail P. Zhurbenko for the linguistic revision and for their helpful comments on an earlier draft of this manuscript. This study received financial support from the Türkiye Bilimsel ve Teknolojik Araştırma Kurumu (TUBITAK, Scientific and Technological Research Council of Turkey; Grant no. 108T566).

\section{References}

Akman, Y. 1999. Climate and bioclimate (The methods of bioclimate and climate types of Turkey). Ankara, Kariyer Matbaacılık Ltd., Şti. Aptroot, A. \& Yazici, K. 2012. A new Placopyrenium (Verrucariaceae) from Turkey. Lichenologist 44(6): 739-741.

Atienza, V.; Calatayud, V. \& Hawksworth, D.L. 2003. Notes on the genus Polycoccum (Ascomycota, Dacampiaceae) in Spain, with a key to the species. Lichenologist 35: 125-135.

Baytop, A. \& Denizci, R. 1963. Türkiye'nin Flora ve Vejetasyonuna Genel Bakış. Ege Üniversitesi, Fen Fakultesi Monografiler Serisi 1: 1-43.

Calatayud, V. \& E. Barreno, E. 2003. A new Lichenostigma on vagrant Aspicilia species. Lichenologist 35(4): 279-285.

Calatayud, V.; Navarro-Rosines, P. \& Hafellner, J. 2002. A synopsis of Lichenostigma subgen. Lichenogramma (Arthoniales), with a key to the species. Mycological Research 106(10): 1230-1242.

Candan, M. \& Halici, M.G. 2009. Two new lichenicolous Arthonia species from Turkey. Mycotaxon 107: 209-213.

Etayo, J. \& Sancho, L.G. 2008. Hongos liquenícolas del Sur de Sudamérica, especialmente de Isla Navarino (Chile). Bibliotheca Lichenologica 98: 1-302.

Etayo, J. \& Yazici, K. 2009. Microsphaeropsis caloplacae sp. nov. on Caloplaca persica in Turkey. Mycotaxon 107: 297-302.

Etayo, J. \& Diederich, P. 2009. Arthonia protoparmeliopseos, a new lichenicolous fungus on Protoparmeliopsis muralis from Spain and Luxembourg. Bulletin de la Société des Naturalistes Luxembourgeois 110: 93-96.

Etayo, J. \& Navarro-Rosinés, P. 2008. Una combinación y tres especies nuevas de Lichenochora (Phyllachorales, ascomicetes liquenícolas), y notas adicionales para el género. Revista Catalana de Micología 30: $27-44$ 
Fałtynowicz, W. 2003. The lichens, lichenicolous and allied fungi of Poland - an annotated checklist. Biodiversity of Poland 6: 1-435.

Halici, M.G.2008. A key to the lichenicolous Ascomycota (including mitosporic fungi) of Turkey. Mycotaxon 104: 253-286.

Halici, M.G. \& Aksoy, A. 2009. Lichenized and lichenicolous fungi of Aladağlar National Park (Niğde, Kayseri and Adana Provinces) in Turkey. Turkish Journal of Botany 33: 169-189.

Halici, M.G.; Hawksworth, D.L. \& Aksoy, A. 2007. New and interesting lichenicolous fungi records from Turkey. Nova Hedwigia 85: 393-401.

Halici, M.G.; Hawksworth, D.L., Candan, M. \& Özdemir-Türk, A. 2010. A new lichenicolous species of Capronia (Ascomycota, Herpotrichiellaceae), with a key to the known lichenicolous species of the genus. Fungal Diversity 40: 37-40.

Hawksworth, D.L. 2003. The lichenicolous fungi of Great Britain and Ireland: an overview and annotated checklist. Lichenologist 35: 191-232.

Hawksworth, D.L. \& Cole, M.S. 2002. Intralichen, a new genus for lichenicolous "Bispora" and "Trimmatostroma" species. Fungal Diversity 11: 87-97.

Hawksworth, D.L. \& Halici, M.G . 2007. Gemmaspora, a new verrucarialean genus with remarkable ascospores for Adelococcus lecanorae growing on Aspicilia species in Syria and Turkey. Lichenologist 39: 121-228.

Hawkswoth, D.L. \& Jones D. 1981. Sclerococcum sphaerale obtained in pure culture. Transactions of the British Mycological Society 77(3): 485-489.

Kocourková, J. 2000. Lichenicolous fungi of the Czech Republic (the first commented checklist). Acta Musei Nationalis Pragae B 55: 59-169.

Navarro-Rosinés, P.; Calatayud, V. \& Hafellner, J. 2009. Contributions to a revision of the genus Cercidospora (Dothideales) 1. Species on Megasporaceae. Mycotaxon 110: 5-25.
Scholz, P. 2000. Katalog der Flechten und flechtenbewohnenden Pilze Deutschlands. Schriftenreihe für Vegetationskunde 31: 1-298.

Santesson, R.; Moberg, R., Nordin, A., Tønsberg, T. \& Vitikainen, O. 2004. Lichen forming and lichenicolous fungi of Fennoscandia. Museum of Evolution, Uppsala University.

Vondrák, J.; Halici, M.G., Kocakaya, M. \& Ondrákova, A.V. 2012. Teloschistaceae (lichenized Ascomycetes) in Turkey. 1. Some records from Turkey. Nova Hedwigia 94: 385-396.

Yazici, K.; Aptroot, A., Aslan, A., Etayo, J., Spier, L. \& Karagöz, Y. 2010a. Lichenized and lichenicolous fungi from nine different areas in Turkey. Mycotaxon 111: 113-116.

Yazici K.; Aptroot, A. \& Aslan, A. 2010b. Three lichenized fungi new to Turkey and the Middle East. Mycotaxon 111: 127-130.

Yazici, K.; Elix, J.A. \& Aslan, A. 2010c. Some parmelioid lichens new to Turkey and Asia. Mycotaxon 111: 489-494.

Yazici, K.; Aptroot, A., Aslan, A., Vitikainen, O. \& Piercey-Normore, M.D.. 2011a. Lichen biota of Ardahan province (Turkey). Mycotaxon 116: 480 .

Yazici, K.; Etayo, J. \& Aslan, A. 2011b. A note about lichenicolous fungi from Ardahan (Turkey). Cryptogamie, Mycologie 32(4): 429-437.

Yazici, K.; Aptroot, A. \& Aslan, A. 2011c. Lecanora wrightiana and Rhizocarpon inimicum, rare lichens new to Turkey and the Middle East. Mycotaxon 117: 145-148.

Yazici, K.; Aptroot, A. \& Aslan, A. 2012. Candelariella, Ochrolechia, Physcia, and Xanthoria species new to Turkey. Mycotaxon 119: 149-156. 